\title{
ECONOMIC PLURALISM AND THE PROCESS OF ENTREPRENEURIAL PLURALISM IN COMMUNITARIAN TOURISM ACTIVITIES DEVELOPED BY THE BELA VISTA DO JARAQUI COMMUNITY - MANAUS - AM
}

\author{
Paula Cristina Pereira Rodrigues Chavesa \\ Francisco Antônio dos Anjos ${ }^{b}$ \\ Helen Rita Menezes Coutinho
}

\begin{abstract}
This study seeks to contribute to discussions related to other economic and entrepreneurial realities existing in Brazil, excluded because they do not fit the globalizing reality, but which contribute, in a way, to the improvement of life in lower social classes, adding in sociocultural aspects, feeding both collective labor forces and the formal economy of many capitalist companies, in which tourism is also inserted. That said, the aim of this article proposes to verify the entrepreneurial pluralism based on the economic pluralism of Zaoual (2006), identifying different entrepreneurial forms related to communitarian tourism developed in the Bela Vista do Jaraqui community, in Manaus-Amazonas. From the perspective of the dialectic of qualitative approach, we conducted field and participant research with the community with the intention of interviewing and observing the entrepreneurial practices related to communitarian tourism. The results point to the presence of entrepreneurial forms, which appear as: Bezamat's turner entrepreneurship (2017), Zaoual's situated entrepreneurship (2006), and Mandrysz's social entrepreneurship (2020). In addition, the studies found some weaknesses in relation to community and institutional arrangements.
\end{abstract}

\section{Keywords:}

Community Tourism

Entrepreneurship

Economic Pluralism 


\section{INTRODUCTION}

The idea for this work came from the approximation of the Amazonas State University - UEA and the Bela Vista do Jaraqui community, which has been taking place since 2013, through the involvement of extension and research projects. Through the endogenous knowledge, and the perception of how the entrepreneurial process affects the socioeconomic and cultural life of the community, the researchers' initiative emerged to understand, from the perspective of Zaoual's economic pluralism (2006) and its existing economic forms, the possible forms entrepreneurs related to community tourism activities, called here in this study of entrepreneurial pluralism, painting the possible endogenous mechanisms adopted and present in the development of activities produced by the community.

The Bela Vista do Jaraqui community is located on the left bank of the Rio Negro, in the rural perimeter of the city of Manaus (AM), in the Sustainable Development Reserve (RDS) Puranga Conquista, and until 2014 lived under the condition of a State Park, which generated many conflicts that partly affected the way of life of the community. Tourism in the community has always been present, however, it was from the categories of conservation units (UC) that began to be appointed, by the managing institutions of the UC, as an economic alternative, capable of promoting cultural appreciation, environmental conservation and income generation (CHAVES, 2016).

In this perspective, which unites economic gain, cultural appreciation and environmental conservation, it is believed that communitarian tourism presents itself as a model that differs from the capitalist entrepreneurial model, based mainly on profit, market competitiveness and the accumulation of wealth, adapting to typologies closer to the situated economic, social and cultural realities present in traditional communities.

Ergo, a discussion is proposed about the other entrepreneurial forms that have long been part of the real economy in Brazil, such as the Brazilian entrepreneur turner cited by Bezamat (2017), a typology that transits between the characteristics of entrepreneurship, however it fits the reality of economic and social need found in various parts of Brazil, adopting strategies to ensure the improvement of life, finding themselves in different forms of work, considered mostly informal.

However, some authors such as Bezamat (2017), Tiriba (2001), Sachs (2003) and Zaoual (2006), draw attention to other entrepreneurial forms that are part of the real economy in Brazil. True survival technologies adopted by a huge contingent of people excluded from the capitalist process that inhabit the under- world of the Brazilian real economy.

Zaoual (2006, p. 179), points out the need for a paradigmatic break with the single economy model, based on the laws of the market, where specifically, "to produce corresponds to the demands of profit and competition", ignoring other socioeconomic mechanisms existing in many realities, proposing there is a need for "a paradigm more respectful of social authors diversity of practices" which he calls "economic pluralism" (Zaoual, 2006, p. 174) and which may also be related to tourist practices developed in traditional communities from the Amazon.

In the conduct of the single dominant economy or in economic pluralism, the entrepreneur appears, considered as a driving agent of the economy, and following this same reasoning, it is stated that in the proliferating environment of the economy other entrepreneurial forms are also present, giving rise to what we call, in this research, of entrepreneurial pluralism.

That said, this article aims to verify the entrepreneurial pluralism based on the economic pluralism of Zaoual (2006), identifying other entrepreneurial forms related to communitarian tourism developed in the Bela Vista do Jaraqui community, in Manaus, Amazonas. This understanding is based on the principle of the theory of economic pluralism, which includes, among others, economies such as: Tiriba's popular economy (2001); proto and pre-capitalist and solidarity economy of Sachs (2003); Mandrysz's social economy (2020). The forms related to the process of entrepreneurial pluralism are related to the forms of economy mentioned above and are related to: Bezamat's entrepreneur turner (2017); situated entrepreneur from Zaoual (2006); and the social entrepreneur of Mandrysz (2020).

For this analysis, it will also be necessary to identify the initiatives of productive arrangements and the existing cooperation mechanisms in the practices of tourist activities. Through the results, it is possible to broaden the discussions aiming to understand ways and strategies more consistent with the entrepreneurial realities found in riverside communities in the Amazon.

\section{COMMUNITARIAN TOURISM AN EN-} TREPRENEURIAL PROPOSAL FOR CULTURAL AND ENVIRONMENTAL VALUE

Tourism is a socioeconomic phenomenon appointed as an alternative to promote regional, local or situated economic development, supporting, in some cases, conservation and maintenance strategies for natural and cultural environments, especially related to traditional populations that are in situations of vulnerability. 
Considered one of the largest activities in the economic sector, tourism represents $10.4 \%$ of the world GDP, with $3.2 \%$ being generated directly by the sector and the remainder by activities related to the tourism production chain. It is estimated that for every 10 jobs created, 1 is related to tourism (World Travel and Tourism Council, 2018).

Considered one of the countries with the greatest natural and cultural patrimony, with biodiversity considered one of the richest on the planet, Brazil attracts thousands of tourists every year. With its territorial extension and its biodiversity largely preserved, the Amazon has become a desired destination, exerting a real fascination on the imagination of Brazilian and foreign tourists who come in search of natural and cultural experiences.

Nature tourism represents a strong trend in the current tourist movement, increasing the already growing demand in the search for recreation in natural environments that can offer direct contact with nature and with the populations residing in these environments and, as a result, it is appointed as relevant to the growth of tourism. (Brumatti, 2014; Hall; Müller; Saarinen, 2009; Marzuki; Rofe; Hashim, 2014; Winter, et al., 2020).

Besides contributing to the growth of tourism, TBN is also considered one of the types of tourism that contributes the most, in relation to other types of tourism, such as nature tourism, ecotourism, adventure tourism and communitarian tourism (Buckley; Pickering; Weaver, 2001; Hall \& Boyd, 2005; Mehmetoglu, 2007).

According to a survey carried out by the Brazilian Tourism Company - EMBRATUR (2018), the interest in nature, sun and beach tourism, as well as sustainable tourism and ecotourism, are on the rise, with a growth of $27 \%$, pointing to be one of the main reasons for traveling to Brazil. And, through the Tourism Market Intelligence Bulletin - BIMT (2018), the tourism motivation of the Amazon Region is centered on ecotourism. These, among other situations, lead us to believe that the greatest appeal of the destination is in fact the nature and culture of residents in natural environments and, consequently, communitarian tourism.

Thus, Silva, Chaves \& Simonetti (2020) highlight that between ecotourism and cultural tourism, emerges community or community-based tourism, as it is also called, in which, they are based on the role of communities during their management, as well as in the effectuation of tourist activities, with the generation of income divided equally.

"In Amazonas, some communities have adopted the term communitarian tourism in the self-definition of tourist activity in their spaces, whether riverside or indigenous, perceiving tourism as an economic alternative" (Silva, Chaves and Simonetti, 2020, p. 475). Bursztyn (2014) observes the importance of the relationship between the resident, visitor and natural environment, in which communitarian tourism is evidenced by favoring cultural and environmental exchange in a way that is not as devastating as traditional or mass tourism.

Thus, communitarian tourism has been identified as a proposal for the protection and conservation of the natural environment, as it contributes to local development by valuing the culture linked to the situs of each location, as opposed to mass tourism (Bursztyn, Bartholo \& Delamaro, 2009).

It is noteworthy that world tourism is gaining new formats, distinct from the dominant tourism and tourist consumption (Zaoual, 2006). The tourist demand has become increasingly demanding in the search for more versatile and varied experiences, adding value of belonging to the visited place, which provide affective memory and cognitive emotions. "The crisis of the reign of quantity opened the door to quality", which does not prioritize the quality of material service, but rather the experiences, emotions and memories of intercultural and environmental exchanges experienced by tourists.

Communitarian tourism came from a movement of traditional populations with the objective of not remaining on the eminence of "losing their rights to exist and to simply maintain their way of life" (Bursztyn, 2014, P. 61). Allied to the process of "sustainable self-management of community patrimony resources, in accordance with practices of cooperation and equity at work and in the distribution of benefits generated by the provision of tourist services" Maldonado (2009, p. 31) considers that communitarian tourism adds gains that go beyond profit and competition, a primordial component for the driving force of capitalism.

According to Maldonado (2009), communitarian tourism has some characteristics that distinguish it from conventional tourism: self-management of community patrimony resources, equitable work cooperation, equal distribution of benefits, encouragement of interculturality through knowledge of the way of local life, having the human and cultural dimension as a preponderant factor of the activity.

Considering that communitarian tourism can develop other socioeconomic mechanisms that are better suited to reality, pointing out other social actors that differ from the capitalist entrepreneurial figure, this study intends to verify other conceptual forms of entrepreneurship that are better suited to the economic experiences present in activities related to tourism developed in the Bela Vista do Jaraqui community, with the intention of presenting the local entrepreneurial reality, in order to help managers, employees and partners in the strategies to support the socioeconomic development of it, as well as other community realities. 


\section{ECONOMIC PLURALISM AND ITS RE- LATIONSHIP TO ENTREPRENEURIAL PLURALISM}

It can be said that entrepreneurship is directly linked to socioeconomic relations, which changes in these environments greatly affect the existing entrepreneurial forms. The same happens with the development of tourism, which cannot be treated as an isolated socioeconomic process, since the development of the activity depends on the relationship with other socioeconomic environments. However, it is important to digress about the process of economic pluralism of Zaoual (2006) so that we can understand the relationships with entrepreneurial pluralism, a term adopted in this study, as a way to understand the existing entrepreneurial forms in the Bela Vista do Jaraqui community.

"Economics studies the relationship that men have among themselves in the production of goods and services necessary to satisfy the desires and aspirations of society" (Vicecont \& Neves, 1996, p. 1), and such a process of production of consumer services is led by the entrepreneur, the main driving agent of economic development, considered "the heroic figure of capitalism" (Zaoual, 2006, p. 174).

Zaoual (2006) points out that the economy is a vision of man who imprinted individualism as the main characteristic of human behavior, destined to produce and distribute to the market according to the demands of profit and competition, these being the main bases of capitalism, which figures as a globalizing economic system, "which is essentially excluding other visions of the world" (Zaoual, 2006, p. 181), and why not say other entrepreneurial visions.

Tiriba (2007) argues that, even if the dominant economy is considered hegemonic, there are still other forms of economy that differ from capitalist rationality, based on the phenomenon of capital accumulation through profit, such as the popular economy, in which its forms of production are concentrated in the popular sectors, transiting as informal or as differentiated forms of producing, distributing and consuming, being worth "anything to survive", in which "labor constitutes the main factor of production, constituting itself as the genesis and, at the same time, the result of the set of other factors in the production process of goods and services." (Tiriba, 2007, p. 2).

The increase in poverty and the lack of employment generated by a system of wealth accumulation, in which economic growth is concentrated in the hands of a minority, are mainly responsible for stimulating informal initiatives. The informal economy differs in time and space from the formal economy, and it is of- ten devalued as part of the economic underworld which, according to Sachs (2003), for some coryphaus of modernization tends to disappear.

According to Krein and Proni (2010), in the early 1970s, the International Labor Organization (ILO) published the first studies on the informal economy sector aimed at urban areas, in which activities were related to activities of low economic productivity and that were carried out by independent or self-employed workers, small businesses that did not operate in a legal and organized manner, paying low wages, offering terrible working conditions, not guaranteeing the social rights of the worker and also acting informally.

It is noticed that the term informal arises from the dominant capitalist economic view, directly related to more developed areas, carrying in itself pejorative aspects. However, from the 1990s onwards, informality took on different debates, gaining new contours, in which urban approaches were no longer restricted and began to comprehend rural areas as well, being identified as relevant for generating income for a significant portion of the population, both urban and rural area. "This led the International Labor Organization (ILO), not only to review its definition of the informal, but also to rethink the set of policies considered more adequate to deal with the diagnosed problems" assuming that there is heterogeneity in informal activities (Krein \& Proni, 2010, p. 12).

Sachs (2003) points out that informality also feeds the formal economy, contributing to increase the financial results of large companies, serving as support for the sale of products produced by these companies, "as already indicated, regarding cosmetics retailers and bag stores, there is a link between the large companies of the capitalist market and the popular economy, achieved through an informal distribution network" (Sachs, 2003, p. 76), which we can conclude, can also be a reality of tourism in traditional communities. Different forms of work or entrepreneurial also feed individual forces and collective forces, in which individual or associative work sustain an economic relationship with a certain number of people who, according to Tiriba (2006), even though they are called "selfemployed workers, there is a certain number of people associated with them" (p. 118). This means that even working individually, it ends up cooperating economically with other individuals who are largely members of their own family or friends and who often work in an associative way united by social ties with the objective of extended life reproduction, nomeados por Tiriba (2007) de nominated by Tiriba (2007) of Oikoworkers. For Castro (2015), this reality of Oikoworkers, as well as the practice of informal work in tourist activity is a very consistent reality in Manaus, Amazonas, showing that there is a two-way street in the use of formal and informal tourist services that, in order to "attend to the interests of the involved ones and to share responsibil- 
ities in the pursuit of their common interests", economic environments are nurtured both by formality and informality, involving several workers in an associative manner, such as "boatmen, hotel receptionists, van drivers, taxi drivers among others" (Castro, 2015, p. 35).

According to Tiriba (2001 and 2003), just differentiating the formal economy from the informal economy is not enough to understand the complexities existing in the fabric of social relations, in which the so-called informality has facilitated the inclusion of lower classes in the dynamics of the global economy. Zaoual (2006) states that the inability to understand economic diversity that would point to new, more desirable socioeconomic initiatives, combined with conceptual impotence "cause the great generalizing model of economic science submerge in the tide of the informal" (Zaoual, 2006, P. 182).

Zaoual (2006) proposes a synergy between the social sciences and standard economics, pointing out that there is an economic pluralism, "which perspectives and philosophy are unavoidable in the analysis of the limits of the standard model in economics", noting that there is a need to build "a paradigm more respectful of the diversity of practices of social authors" (Zaoual, 2006, P. 174).

On the other hand, the appreciation of the pluralist economic paradigm is necessary for the continuity of socio-economic biodiversity, "which disappearance constitutes a threat, even to the dominant economic system itself", which excludes other economic forms that have emerged as a result of the ills generated by this unique economy (ZAOUAL, 2006, P. 181). "By itself, the economic world, as perceived, does not correspond to the totality of the world which variety is infinite. A different view is suggested to us by the pluralism of the social theory of sites" (Zaoual, 2006, p. 181). The dominant capitalist economic model and its way of working based on profit, market competitiveness, professional knowledge and technology affect urban areas, and especially rural areas, where access to knowledge is lower, the rate of illiterates is greater, intellectual capital is largely formed by traditional and family knowledge, work, including tourist activities, is not guided by profit, constituting production by labor power to ensure, mainly, subsistence and life.

Bezamat (2017) points out that economic movements had a great participation in the conception of entrepreneurship in the current molds, in which the academic debate on the subject of entrepreneurship was marked and adopted by foreign models aimed at the formal business area, but it is not the possession of the capital and not even the simple management of an organization that will define it. "There is not, yet, an epistemological concern here in the sense of an entrepreneurial theory in Brazilian style anchored in our values" (Bezamat, 2017, p. 20).
This Brazilian entrepreneurial theory of Bezamat (2017) is linked to the famous Brazilian knack present in the Brazilian ethos, a way of acting and thinking to solve the difficulties encountered, actions that cannot only be seen as Brazilian folklore, but as a reality found in the underworld of the informal economy for a long time, "[...] the Brazilian knack [...] it is actually about the conformation of a peculiar ethos that provided our social ingenuity, our way of acting and thinking, both in the aspects of subjective nature and external nature, social and economic world" (Bezamat, 2017, p. 22).

For Tiriba (2004), the capitalist model that generates wealth also generates ills and poverty, leading the excluded or marginalized to the precariousness of life, forcing new forms of work or new forms of entrepreneurial activities. These people who are part of "economic pluralism" and, why not say, entrepreneurial pluralism, who fight for the maintenance of life, relate to Bezamat's turners (2017), representing a contingent of excluded because they are informal, however, according to author Tiriba, they are experts in "survival technologies".

The turner, according to Bezamat (2017), represents this Brazilian knack, a way that is part of the Brazilian culture evidenced in the populations of rural societies and communities that seek within their conditions, often considered informal and without academic and professional knowledge, a way to guarantee the generation of income for their families. The author also makes reference to the critique of entrepreneurial obstinacy discussed by Zaoual (2006), in which it obscures the notion of the situated entrepreneur - related to symbolic sites of belonging - economic entrepreneur - linked exclusively to capitalism and globalization.

Bartholo (2014) warns about the indeterminate use of the term community, since in many situations it is associated with economic determinism. According to the author, this is an erroneous perspective related to globalized modernity, in which the logic of homo economicus is used for local development. However, it indicates that in the tourism process in communities, the core of the issue is the identity and belonging elements, symbolic sites of belonging, represented by the homo situs, which suggests an economy that values the values of belonging, culture and the modus vivendi and not the market economy.

Therefore, it is concluded that among the forms of economy present in economic pluralism, new entrepreneurial forms emerge, which we chose to call entrepreneurial pluralism, which in turn emerges as an action figure, developing different forms of the dominant capitalist economy and the economic entrepreneur (Bartholo, 2014), rising the entrepreneur from Bezamat (2017) and the situated entrepreneur from Zaoual (2006).

Sachs (2003) points out the need to understand the 
real economy of Brazil, paying attention to activities produced in rural areas, as these actions, in addition to keeping the rural population in the countryside, reduce urbanization costs to accommodate the rural exodus.

That said, other types of economy present in economic pluralism and that transit mainly in rural areas drew attention during the studies developed here, such as the proto and pre-capitalist economy, and solidarity economy cited by Sachs (2003) and the social economy of Mandrysz (2020).

The proto and pre-capitalist economies include forms of production or of work that differ from capitalist forms, such forms are not associated with profit, but rather by the strength of labor and its value. They are called pre-capitalist because they come from community, artisanal and traditional forms of work, carried out informally and without a business organization considered, in most cases, outdated and with little participation in economic growth. These activities considered informal by the dominant economy, in some cases nourish large enterprises, contributing to global economic development (Sachs, 2003).

The solidarity economy, in turn, indicates a form of production governed by valuing the individual and not capital, its main characteristic is the self-management that can be found in cooperatives or companies selfmanaged by the workers themselves. (Sachs, 2004, p, 75).

The origin of the solidarity economy manifested itself soon after the emergence of industrial capitalism, as a response to the impoverishment of artisans who lost the value of their work in favor of the propagation of industrial work. The first idea of a cooperative emerged in 1817, in Great Britain, by Robert Owen, who, concerned with poverty and labor exploitation, suggested a proposal for Cooperative Villages, where people would work the land and industries and guarantee their livelihood, and the surplus production could be exchanged between the villages, this would guarantee a decrease in public spending on aid to the poor and would return a layer of idle workers to labor productivity, generating an economy of resources (Singer, 2002). The solidarity economy has been identified as a way out to face the economic inequality established by capitalism. The union of popular sectors can greatly solve social problems, such as employment opportunities and poverty alleviation. According to Singer (2002, p.9), "for us to have a society that predominated equality in all its members, it would be necessary for the economy to be solidary rather than competitive".

Aimed at improving life, the solidarity economy has other characteristics that differentiate it from other forms of production, its basic principles are "the collective or associated ownership of capital and the right to individual freedom" (Singer, 2002, p. 10). This type of production unites all those involved in production in the same category of workers who participate in equal forms of remuneration. However, the application of a solidary basis in the economic system is not an easy-to -reach process, due to the situation of the social structure itself already developed and rooted in society or even in communities.

In order to verify the institutions that participated as active in the production and cooperation arrangements, it was also sought to understand the social economy of Mandrys (2020), which constitutes a wide range of activities offered by social enterprises that include non-profit organizations, as well as associations, cooperatives, mutual organizations and foundations, particularly active in certain areas, such as social protection, social services, healthcare, banking, insurance, agriculture production, consumption issues, associative work, crafts, housing, supplies, neighborhood services, education and training, and the area of sports, culture and recreation, among others (Mandrysz, 2020).

The main objective of the social economy is to solve social problems in a participatory and collaborative way, offering opportunities for economic regeneration to people from local communities or who are in a situation of vulnerability. The social economy, like other economies, is distinguished by its dominant entrepreneurial characteristics, based on the concepts of coproduction, social resourcefulness and cooperation. It is noteworthy that its function is to support public institutions, not replace them, and its support activities are not restricted exclusively to economic regeneration, acting in the provision of different types of social services, depending on the social problem encountered. (Mandrysz, 2020).

The definition of social economy highlights the innovative role of entrepreneurship and its social engagement, pointing out the existence of social entrepreneurs, defined by their innovative role in the face of social problems and active position in the community, they are considered agents of change in the social sector. "They make fundamental changes to the way things are done in the social sector. Creating systematic changes and sustainable improvements, "they are co -managers of public services and co-producers of social services" (Mandrysz, 2020, p. 3).

\section{MethOdOLOGICAL ASPECTS}

Based on the dialectical method, this research, with a qualitative approach, aimed to understand, from the perspective of Zaoual's economic pluralism (2006), the entrepreneurial pluralism, present in activities related to tourism practiced in the Bela Vista do Jaraqui community, starting from the principle, that this reality is also present in other communities in the Amazon Re- 
gion.

We opted for the explanatory research, as it seeks to understand the socioeconomic mechanisms used in the practices of activities related to communitarian tourism and the economic process and the entrepreneurial transformation facing the alternatives found and developed by the community, governmental and non-governmental institutions.

In this perspective, secondary means were used, which comprised the bibliographic study, bringing together the theoretical support necessary for the study; and primary, through semi-structured interviews and observations.

Because there is a need for interaction between researcher and members of the investigated situations, both field research and participant research were important procedures that were added to the application of interviews, in which a qualitative approach was used to understand the collected information verified as the most adequate to the needs of the study. Gil (2008) emphasizes the importance of the approach and its relationship with the procedures, where the analysis of research information using these procedures "[...] are mainly qualitative in nature" p. 175).

As for the selection of subjects in the research sample, the intentional non-probabilistic sample was chosen. Therefore, 10 representatives of families that develop tourism in the community took part as research subjects, as well as 03 community leaders and 04 owners of commercial establishments, comprising a total of 17 interviewed subjects.

As for the interviews, we opted for semi-structured interviews, being applied, in large part, collectively, with family members of legal age, and individually, with community leaders and owners of establishments. The interviews were recorded using a notebook (notes) and tape recorder. In the notes, the main information was noted more objectively, punctuating the most relevant information, while the recorded information helped in the transcription of texts highlighting the details informed.

The analysis and interpretation of the data were carried out after organizing the results found in the qualitative research, which allowed to analyze and highlight the existing relationships between the types of economy and types of entrepreneurships developed in relation to activities related to communitarian tourism. And with the intention of structuring the results showing such relationships between pluralism and entrepreneurship, the study had four categories of analysis: the emergence of tourist activities and the current scenario; the stages of development of tourist activities and external participation; the benefits generated; the challenges in the tourist activity development process; the involvement of institutions, their participation and contributions.

\section{RESULTS}

\section{Arising of Tourist Activities and the Current Scenar- io}

According to the survey, two situations marked the origin of tourist activities in the community: one through travel agencies that sought to aggregate activities related to traditional knowledge and the community way of life in their tourist itineraries; and the other through the implementation of Rio Negro State Park, which, in addition to having greatly limited traditional activities, aimed to remove the populations residing there. In the last situation, tourism is seen as one of the main activities that would help communitarians in income maintenance, in environmental preservation, and in the opportunity to remain residing in the community itself, as long as the Park category was not changed.

Tourism was initially introduced in the community in the 70 s, when a small part of the community began to be sought out by travel agencies to conduct water and land trails with the intention of introducing tourists to their traditional knowledge related to the Forest. According to reports, in the beginning they were only sought by one agency, however, today this number is much higher: "before there was practically only one agency that I was lookied for, just me and another one who worked with tourism, now there are hundreds of agencies" (a report of one of the oldest residents of the community and one of the first to work with tourism).

In 1995, with the creation of Rio Negro State Park, tourist activities began to be even more valued and encouraged by regulatory agencies, as an alternative for income generation, since a large part of rural practices, such as fishing, agriculture, among others, presented themselves as threatening to the objectives of the park. At this time, governmental and nongovernmental institutions were beginning to be part of this environment by implementing new knowledge to support the development of tourism and other activities.

Gradually, activities related to tourism are increasing in the community. Today, tourism is developed by 5 families that, throughout the year, receive a representative quantity of groups of tourists to learn about the community's way of life and practice activities such as: jungle trek, canoe tour, jungle survival, knowledge about medicinal plants, among others.

In addition to the income opportunity for these 5 families, tourism impacts other communities that carry out sporadic support activities for families who, depending on the size of the group of tourists received, are called upon to assist in activities such as guidance, preparation of meals, production of handicraft, general clean- 
ing, organization of reception spaces, etc.

\section{The Stages of Development of Tourism Activities and External Participation}

There were some stages observed in the entrepreneurial development of the tourist activity that began to be developed according to the arising of tourist activity in the community.

In the first stage considered entrepreneurial, it is initially observed an innovative initiative from the moment when the community, even without professional knowledge, sees the opportunity of tourist activity as a new form of work and income, contributing to their financial needs. Set up an informal service provider, completely innovative, since it was a different activity from its traditional practices. At this moment, a redefinition of social and cultural aspects is perceived, in which the way of life and traditional knowledge are introduced in the process of creation and development of entrepreneurial tourist activity.

In this situation, it is possible to observe the presence of two entrepreneurial forms that appear as: the turner of Bezamat (2017), in which the community, without knowledge about tourism, develops the activity through the Brazilian ethos, and why not say, community ethos, giving a Brazilian knack as a way to develop the activity and resolve their difficulties; and the situated entrepreneur of Zaoual (2006), in which the activity is developed under the combination of knowledge of the tourist activity with the values of symbolic sites of belonging, in which the commercialization of the service uses the power of labor, acts as the main component of distribution and configures itself in a situated entrepreneurial activity, which differentiates it from the economic entrepreneur (ZAOUAL, 2006), approaching both the pro and pre-capitalist economy (Sachs, 2003) and the popular economy (TIRIBA, 2001 and 2004).

As the time passed, this reality gained new proportions in the search for the organization of the activity, adapting itself to tourist demands, with this activity gradually gaining new communities and infrastructure for development. According to the reports of community residents, in the past they only received the group of tourists and guided them through the forest, presenting their knowledge. Over time, communitarians involved in tourism have adapted new services and facilities, so that they can adapt to the demands arising from the tourism offer and needs.

Today, the community has an adequate infrastructure to support the development of tourist activities, with 04 ecological trails, 02 inns and 03 camps used for activities of survival in the jungle, with hammocks, bathrooms and space to carry out meals, as you can note in Figure 1.
Figure 1 - Part of the Tourism Support Infrastructure

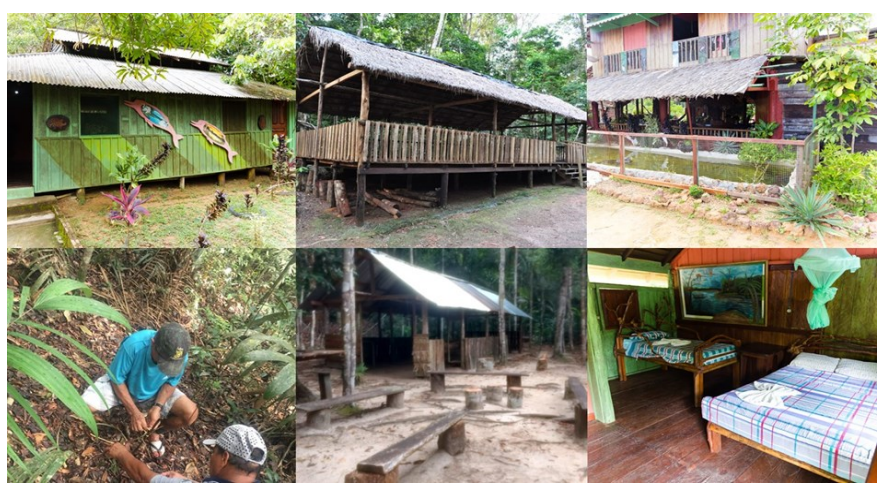

Source: Photos taken by researcher Chaves,P. C. P. R. (2020).

According to the reports, the tourist activity was intensified according to the demands verified by the tourists and the demands of the tourist companies themselves, that grew little by little, "things started to change about 20 years ago when a group from Europe and São Paulo started coming here and they asked to make a camp in the middle of the forest" (report of a communitarian that works directly with tourism). According to this report, it was possible to notice that there is an integration of formal companies in the activities provided by the (informal) communitarian, evidencing the "two-way street", both in the use of services and in meeting the needs and responsibilities between both parties. However, despite this integration and the direct influence of formal companies in the development of tourist activities, the features of local symbolic sites are still strong, pointed out by Zaoual (2006, p. 38 and 39), "the entrepreneurial rationality and its implementation are also located. When carried out effectively, they integrate the contingencies of the place and, simultaneously, capture from abroad loans that are molded in the endogenous processes of the site."

Entrepreneurial rationality is related to situated rationality, in which homo situs is part of a social construction that constantly adjusts due to the place and the dynamics presented to it. From this perspective and in the touristic experience developed in the community, it is recognized that in communitarian tourism the unique aspects are eminently affected by external agents, in this case, represented by formal tourism companies and tourism demand, however, this situated plasticity establishes, at the same time, cultural limits to its influence (ZAOUAL, 2006).

\section{The Benefits Generated}

In this part of the research, it was found that the benefits generated went beyond the financial aspect. When asked about the knowledge used for the development 
of this support infrastructure, the communitarian informs that: "Here we have to manage as we can, knowledge was the one God really gave me, after a long time the organs came, but I was already working with this, and I became an example in the meetings, I even passed my knowledge in meetings in other communities" (report of a communitarian that works directly with tourism). Again, the Brazilian knack of shaping the turner (BEZAMAT, 2017) is present, as well as the situated entrepreneur (ZAOUAL, 2006), who finds a solution to the tourist needs, without these changes failing to safeguard their cultural singularities and their values. It is also noticed the empowerment of this practice as an economic alternative being shared in other realities, including in the community itself, in which, as a consequence, influenced other community members, surpassed economic values and extended to social values and well-being.

According to Maldonado (2009), communitarian tourism outweighs economic gains and this reality was diagnosed when asked about the contributions of tourism to their lives, in addition to financial gains, communitarians stated that financial gains are not as representative. Tourism as an alternative of work also provided comfort, happiness, satisfaction and environmental valuation.

" Tourism gives a little change, but with tourism we don't have to kill ourselves, dealing with weed is very difficult and little money, in tourism I work happier, I feel I'm valued, teaching all those tourists, wanting to know what I know" [...] "today, each plant, each animal is important for my work, because I no longer live by harvesting wood, hunting, the knowledge I have with the forest is important (Report from one of the communitarians who works directly with tourism).

Also according to communitarian reports, tourism contributed to the formation of other types of work, necessary for the development of the activity, such as canoe men, boatmen, foresters, cooks and artisan producers, activities that even in the informality, transit in the popular economy (TIRIBA, 2001 and 2004) or proto and pre-capitalist (SACHS, 2003), which consist of knowledge related to the communitarian ethos and, in some cases, professional knowledge acquired largely through collaborative arrangements between governmental and non-governmental institutions.

The constitution of these "situated activities" unites traditional knowledge, and in some situations, professional knowledge goes beyond local economic contributions. Moving in the popular economy as in the proto and pre-capitalist economy, they corroborate for the economic results of large formal and capitalist companies such as travel and tourism agencies, national and international tour operators, transport companies, besides other companies in the field of food, tooling, nautical equipment, fuel distributors, etc., indirectly contributing to the dominant formal economy, as already pointed out by Sachs (2003).

In addition to tourist enterprises, 11 types of informal businesses were identified, which also transit the popular and proto and pre-capitalist economy that corroborate with large formal companies: four small sales points that offer products such as stowage, cleaning and hygiene products, some perishable foods, an artisan bread sale, a cosmetics sale, a clothing sale, four fuel and gas sales points and a bar. In Figure 2, you can see some of these examples.

Figure 2 - Examples of other types of informal trades that sustain the dominant traditional economy

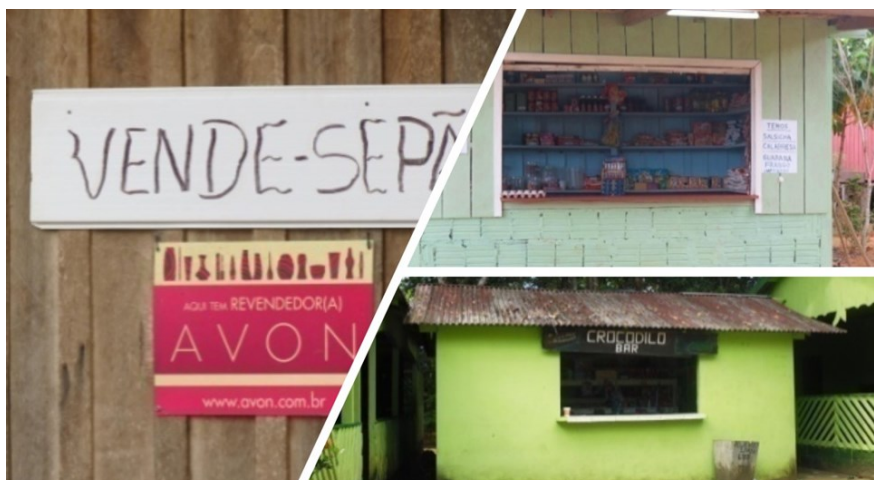

Source: Photos taken by researcher Chaves, P. C. P. R. (2020).

We can also consider that this turning process is present in the development of tourist activity, in new ways of working, in the construction of infrastructure and in the marketing of its activities and products, has a direct relationship with the creative and innovative process that can be considered as true survival technologies (TIRIBA, 2001 and 2004). They are thus considered due to the difficulties that the communitarian sees himself in and the need to seek new entrepreneurial ways, as a solution for economic maintenance.

During the field research, at the home of one of the community members, we identified an example of innovation in the entrepreneurial turner process, a machine for processing seeds, built with old washing machine motors, sandpaper and PVC pipes, shown in Figure 3. An appropriate technology, built with recycled materials, created by the communitarian to meet the need to improve their handicraft items due to the lack of financial resources to buy an industrialized machine. According to the communitarian, the idea came from him, and it greatly facilitates the work of the artisan who works with small seeds, and the difficulty of sanding one by one made the artisan think of a more efficient process, which we identified as an innovation in the turner process a way to solve seed processing. 
Figure 3 - Turning innovative process in seed processing for handicraft production

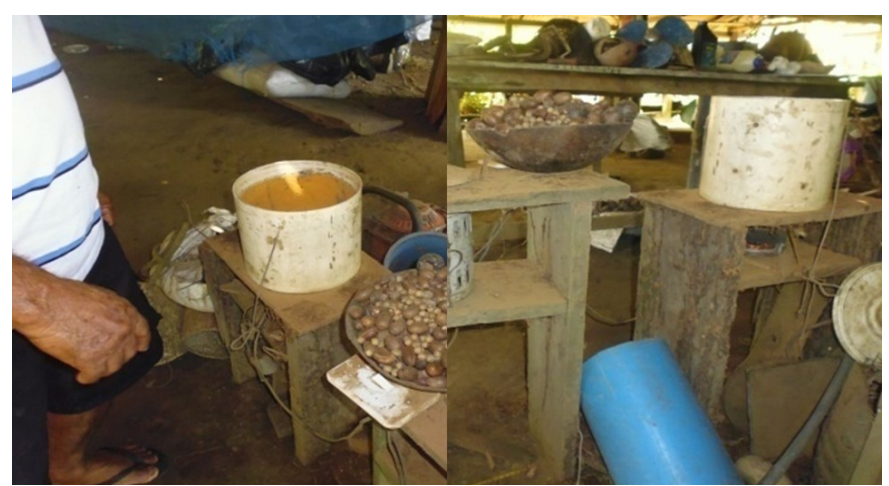

Source: Photos taken by researcher Chaves,P. C. P. R. (2020).

\section{The Challenges in the Tourism Activity Develop- ment Process}

According to communitarians, there are many problems faced in the commercialization of tourism that prevent them from acting independently from other formal institutions: the little knowledge in the tourism trade and in the quality of service without this altering the benefit experienced by the tourist of experiencing the local reality; difficulties in the formation of tourist routes or products; lack of dissemination and promotion of their services, which is restricted to word of mouth, limiting tourist demand; the lack of credibility on the part of agencies and tour operators of the services offered, which often limit the services offered by the communitarians; the depreciation of the values of their services by tourism agents; lack of legal formality in the tourist business, resulting in a lack of autonomy in marketing; in addition to the difficulties in accessing investment support.

Bursztyn (2014) points out that commercialization is one of the biggest problems faced by community tourism in Brazil and in addition to these situations, the author points out other issues that do not differ from the reality found in Bela Vista do Jaraqui community, they are: the difficulties of access due to being far from the urban center of Manaus, and the deficiency in communication, both cell phone and the internet, which in the community are deficient, greatly influencing the development strategies of activities related to community tourism.

The dependence on formal companies is still present and it is pointed out by community members as something that, on the one hand, contributes positively to development and, on the other hand, reduces the role of communitarians in the management of activities. Despite the difficulties and the need for the intermediation of formal companies, this community role in the development of tourism that has been gradually get- ting stronger, but is still seen as a challenge for the community. Today the community already receives tourists who look for them on their own, without the presence of intermediaries, however, this number is still negligible, demonstrating a relationship of dependence for the development of the activity. Therefore, governmental and non-governmental organizations have been working in the community for some time with the intention of contributing not only to the development of tourism and other activities, but also to strengthen the autonomy of the communitarians involved in the development, management and marketing of activities, one of the pillars of community tourism.

Therefore, it is considered that tourism developed in the community, despite receiving external influences in the management of activities, nevertheless has direct relationships with community tourism, due to the identified characteristics that meet part of the conceptual principles pointed out by Maldonado (2009), they are: the cultural exchange that includes experiences related to the community way of life, the role of families in the planning and development of part of the activities and for presenting equity in the planning of activities and benefits. However, it was realized that some challenges need to be overcome for the community to definitively assume the leading role in tourism management.

The involvement of institutions, their participation and contributions.

According to reports from communitarians, the presence of the social economy is noted through the initiatives of social actors and entrepreneurs who promoted actions with the intention of offering opportunities to support communitarians in relation to activities related to tourism. Such actions have taken place since 2003. Table 1 shows the actions taken, the institutions involved and the year.

Table 1 - Institutions that promoted actions to support the development of tourism

\begin{tabular}{l|l|l}
\hline YEAR & INSTITUTIONS & DEVELOPED ACTIVITIES \\
\hline 2003 & $\begin{array}{l}\text { Nilton Lins Private Uni- } \\
\text { versity. }\end{array}$ & $\begin{array}{l}\text { Tourist Inventory carried } \\
\text { out by students of the } \\
\text { Tourism course. }\end{array}$ \\
\hline 2003 & $\begin{array}{l}\text { Brazilian Micro and } \\
\text { Small Business Support } \\
\text { Service (SEBRAE-AM). }\end{array}$ & $\begin{array}{l}\text { Tourism Awareness } \\
\text { Workshop. }\end{array}$ \\
\hline 2005 & $\begin{array}{l}\text { Amazon Communitari- } \\
\text { an Tourism Center } \\
\text { (CENTRAL) }\end{array}$ & $\begin{array}{l}\text { Communitarian tourism } \\
\text { project with the devel- } \\
\text { opment of meetings and } \\
\text { workshops. }\end{array}$ \\
\hline 2006 & $\begin{array}{l}\text { State for the Environ- } \\
\text { ment and Sustainable } \\
\text { Development (SDS), } \\
\text { current State Secretari- } \\
\text { at for Environment and } \\
\text { Sustainability (SEMAS) }\end{array}$ & $\begin{array}{l}\text { Course on Touristic } \\
\text { Route for Visitation at } \\
\text { Rio Negro State Park - } \\
\text { South Sector. }\end{array}$ \\
\hline
\end{tabular}




\begin{tabular}{|c|c|c|}
\hline 2010 & $\begin{array}{l}\text { Sustainable Amazon } \\
\text { Foundation (FAS) }\end{array}$ & $\begin{array}{l}\text { Communitarian Tourism } \\
\text { Projects and Bolsa } \\
\text { Floresta, with meetings, } \\
\text { workshops and courses. }\end{array}$ \\
\hline 2011 & $\begin{array}{l}\text { Institute for Ecological } \\
\text { Research (IPÊ). }\end{array}$ & $\begin{array}{l}\text { Community-Based Tour- } \\
\text { ism Planning Project, } \\
\text { which featured several } \\
\text { courses and workshops. }\end{array}$ \\
\hline 2014 & $\begin{array}{l}\text { Amazonas State Uni- } \\
\text { versity (UEA), involving } \\
\text { professors and stu- } \\
\text { dents from the tourism } \\
\text { course. }\end{array}$ & $\begin{array}{l}\text { Project "Communitarian } \\
\text { Tourism: promoting } \\
\text { local development in } \\
\text { Bela Vista do Jaraqui } \\
\text { Community (Manaus- } \\
\text { AM)", which included } \\
\text { workshops, courses and } \\
\text { research on tourism } \\
\text { activities. }\end{array}$ \\
\hline 2018 & $\begin{array}{l}\text { Amazonas State Uni- } \\
\text { versity (UEA), involving } \\
\text { professors and stu- } \\
\text { dents from the tourism } \\
\text { course. }\end{array}$ & $\begin{array}{l}\text { Project "Tourism in Bela } \\
\text { Vista do Jaraqui Com- } \\
\text { munity (Manaus - AM): } \\
\text { preparing to receive the } \\
\text { tourist", with meetings, } \\
\text { courses, workshops and } \\
\text { research. }\end{array}$ \\
\hline 2019 & $\begin{array}{l}\text { Brasilíndia Group - } \\
\text { Between Ties of Souls } \\
\text { (An exchange project } \\
\text { between Brazil and } \\
\text { India) and the Secre- } \\
\text { tary of State for the } \\
\text { Environment (Sema) }\end{array}$ & $\begin{array}{l}\text { Courses and workshops } \\
\text { on traditional medicine. }\end{array}$ \\
\hline
\end{tabular}

Source: Produced by researchers (2021) based in part on studies by Silva, Chaves \& Simonetti, (2020).

From the analyses, a collaborative network between governmental and non-governmental organizations can be observed, contributing to the co-production of activities related to tourism. We can say that each manager and representative played the role of social entrepreneur mentioned by Mandrysz (2020), from the moment they engage socially in face of the difficulties encountered in the community, presenting an opportunity, guiding the communitarian in improvements for tourism development, that will result in economic gains for the community. According to one of the communitarians:

The help of these bodies is very important to us, they show how we can work better, they bring us knowledge that we sometimes didn't think itnwas important, such as the issue of lifeguards in water trail activities, the information we have to give for tourists, before entering the forest, we here are used to entering the forest barefoot, so we didn't worry about that, this brings more security to our activities (report by one of the communitarians).

An example that caught our attention was the action organized by Instituto Brasilíndia, which promoted an exchange of experiences between communitarians knowledge and meditation techniques and traditional Ayurvedic medicine, from India. The activity developed in April 2019, had the support of the State Department for the Environment - SEMA. Those responsible for the action who configured themselves as social entrepreneurs contributed to the knowledge of the production of living pharmacy beds and the production of oils and plant extracts. This initiative encouraged the organization of a group of 12 women, called Grupo Jatobá, who already worked with fruit processing and candy production and started to produce medicinal oils and syrups. From this initiative also rose another group of women who began to develop a line of natural cosmetics, called Yara da Amazônia Products. Figure 4 shows the products produced by the two groups of women.

Figure 4 - Examples of initiatives arising from social entrepreneurship

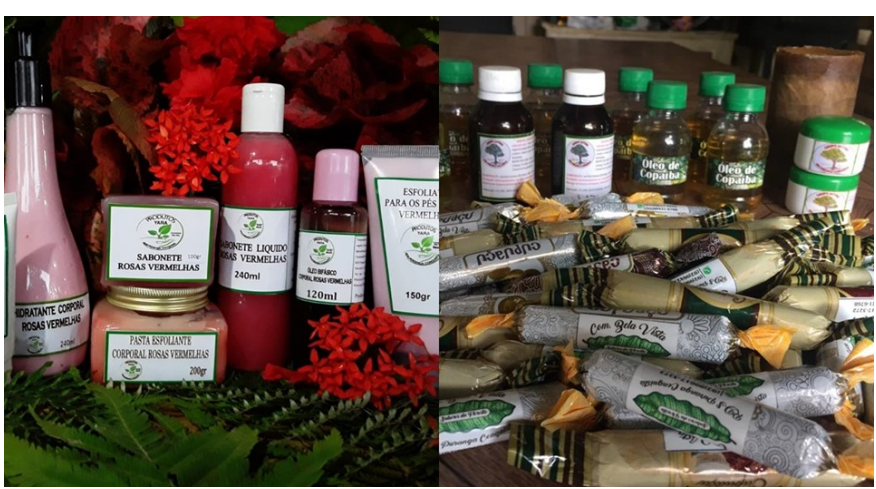

Source: Photo available in the communitarians' personal file.

It is observed that these initiatives, configured as social services, adapting to the principles of the social economy, in which they not only created opportunities for income generation, but also influenced the female empowerment in the community, valuing the traditional culture of the communitarians. In these initiatives, the main agent is the figure of the social entrepreneur, who by innovating in knowledge and production processes, promoted improvements and introduced a new activity in the community (Mandrysz, 2020).

Another example to be pointed and that transits both in the social economy and in the solidarity economy of Sachs (2003), is the program of the Communitarian Tourism Network in Rio Negro (TUCORIN), coordinated by Ecological Research Institute (IPÊ) and Nymuendaju Non-Governmental Organization, an initiative that encompasses six communities, including Bela Vista do Jaraqui community, which emerged in 2008, with the objective of promoting both the integration of riverside communities and tourists and the generation of 
income for the communitarians. This initiative led to the consolidation of tourist activities, which provided equal income opportunity among those involved. According to communitarians, some tourists visited them through this program, although most came from tourism companies or by word of mouth.

The organizations of Jatobá, Yara groups and the communitarian tourism itself, developed by part of the community, can be pointed as examples of the solidarity economy, as they include the equal distribution of income among those involved, but they are not yet formally constituted as cooperatives, only as an association, it is noteworthy that communitarian tourism, as well as Jatobá and Yara groups, are included as an activity belonging to the Association of Traditional Peoples and Communities (APCT).

We found other examples of solidarity economy, such as Rural Agricultural Association for the Development of Bela Vista Community Residents (AGRIMBEL), an association of private rights and without economic purposes, established in 2003, with an average of one hundred communitarians associated, however, according to reports of residents and current and former presidents, there has not been any project involving the community or part of it aimed at agricultural production yet.

Besides AGRIMBEL, Rede Tucumã was identified, an association that involves, in addition to Bela Vista do Jaraqui community, 29 communities on the left bank of the lower Rio Negro. Founded on August 4, 2014, by the initiative of the communities' farmers themselves, also involved in the Eco-Polos Amazônia XXI project, a project conducted by the Ecological Research Institute - IPÊ, which aims to develop sustainable production chains in rural areas. Rede Tucumã follows this same context and aims to strengthen the production and sale of local agrobiodiversity products.

According to reports by one of those involved, Rede Tucumã has already obtained some satisfactory results, especially in terms of the construction of the headquarters and the acquisition of a boat to transport the production, in addition to the articulation for marketing at the Organic Fair of Manaus and with the Food Acquisition Program (PAA) of the National Supply Company (CONAB).

It is realized that social and solidarity initiatives can greatly contribute to income generation and, in some cases, solve marketing problems encountered by communitarians. However, the difficulty of stimulating, managing and putting into practice collective activities in Bela Vista do Jaraqui community was reported, mainly due to conflicts in relations between the communitarians themselves and the lack of financial support.

According to Silva, et al. (2020), if the initiatives do not have endogenous motivations and desires of social groups, they will hardly result in local development. A socializing process is needed among those involved, so that they are protagonists in the development of tourist activity and not simply hegemonic subjects.

Another situation realized was the need for articulation between families that develop tourist activities with families that practice other activities offered in the community, such as handicraft. The creation of a collective production network would favor all families in the community and, with this, would expand the offer of services and products related to tourist activities.

\section{Final Considerations}

According to the results, it can be inferred that the communitarian tourism developed in Bela Vista do Jaraqui community differs from the dominant capitalist economic model, in which the relationship among man, culture and work force are the main pillars of the activities.

The results demonstrate that there is in the community, the presence of economic pluralism, with the presence of the proto and pre-capitalist, solidary and social economy, as well as entrepreneurial pluralism, in which the figures of the turning entrepreneur, the situated entrepreneur and the social entrepreneur border the activities developed by the community, from a perspective outside the dominant economic and entrepreneurial model, present themselves even if informal and without professional knowledge - income generation, cultural enhancement and social well-being. Therefore, they represent the "local" interpretation of tourism, in view of the projections of demands and scenarios of the social group of the destination, against the backdrop of the dynamics of the globalized world, but not the impositions of globalization" (IRVING, 2009, p.111). Despite the performance of governmental and nongovernmental arrangements, which for nearly 18 years have been contributing to the development of activities related to communitarian tourism, there are still many problems faced by communitarians in the development of tourist activities, which prevent them from acting in an independent way. Aspects related to commercialization were identified as the main adversity. However, issues related to the lack of basic community infrastructure affect the well-being of the community and the development of tourism. Another situation verified, in relation to interpersonal and social issues, were internal conflicts and difficulties in managing, stimulating and putting into practice collective activities in the community.

That said, it is realized the importance of representatives of the "social" and "solidarity" economy in the construction of more participatory productive arrangements that promote or intensify social connections 
through mutual cooperation, deepening interpersonal relationships in the community, expanding networks of commercialization of tourism, creating a more comprehensive and efficient articulation including other communities and other activities related to tourism, such as handicrafts or other businesses that already exist or that can be encouraged to exist, supporting them mainly concerned to commercialization.

In addition, some aspects related to infrastructure, especially problems in relation to communication that have made it difficult to integrate the activity with other issuing destinations, difficulties in the development of marketing strategies and the legal formalization of the activity itself.

Therefore, partnerships with government and communication institutions are suggested to increase the communication network in a more comprehensive way and if possible, that can include other communities.

It is also recommended that future institutional initiatives seek to increase the sense of trust between communitarians and collaborative arrangements, in order to strengthen collaboration networks and increase the possibilities of new investments by these institutions, even generating the possibility of acquisition of financial resources for the development of activities related or not to tourism, besides to enabling the increase in the number of communitarians involved. However, it is necessary that institutions do not fail to emphasize the importance and appreciation of cultural aspects, so that activities do not lose traces of local symbolic sites or the community and riverside cultural identity.

It is believed that with such initiatives, community protagonism in the management of tourist activities can be strengthened and, therefore, it is believed that it will be possible to reduce dependence on formal institutions in the development of activities, as well as increase the strengthening of practices of communitarian tourism in Bela Vista do Jaraqui community.

In the scientific field, other studies that can evidence the economic participation of tourism in communities are recommended, in addition to further expanding the direct verification of institutional actions and their generated results, in order to emphasize and expand suggestions and directions that improve the effectiveness of earnings and benefits generated to communities.

\section{REFERENCES}

Bartholo, R. Sobre o lugar do Turismo de Base Comunitária IN: NOVO, Cristiane B. M. C. e CRUZ, Jocilene G. Organizadoras. Turismo de Base Comunitária - Reflexôes no contexto Amazônico. Manaus - AM، EDUA, 2014.

Bezamat, S. N. Contribuição e elementos para um metamodelo empreendedor brasileiro: o empreendedorismo de necessidade do "virador". São Paulo, Editora: Blu- cher Acadêmico, 2017. ISBN 978-85-8039-157-2 (ebook).

Brumatti, P. N. M. Sociedade, cultura e natureza: influências do ambientalismo no desenvolvimento do ecoturismo. Caderno Virtual de Turismo, v. 14, n. 3, 2 dez. 2014.

Buckley, R.; Pickering, C.; Weaver, D. B. Nature-based tourism, environment, and land management, (2001).

Bursztyn, I.; Bartholo, R.; Delamero, M. (2009). Turismo Para Quem? sobre caminhos de desenvolvimento e alternativas para o turismo no Brasil. In: Bartholo; Sansolo; Bursztyn. (org.). Turismo de Base Comunitária: diversidade de olhares e experiências brasileiras. Rio de Janeiro: Letra e Imagem.

Bursztyn, I. Comercialização no turismo de Base Comunitária: Inovar é preciso!'IN: NOVO, C. B. M. C. e Cruz, J. G. Organizadoras. Turismo de Base Comunitária - Reflexões no contexto Amazônico. Manaus - AM, EDUA, 2014

Chaves, P. C. P. R. As Transformações no Trabalho e no Modo De Vida Da Comunidade Bela Vista do Jaraqui - Manaus - AM. Dissertação de Mestrado, Programa de Pós-Graduação em Sociedade e Cultura na Amazônia (PPSCA) - Universidade Federal do Amazonas (UFAM), 2016.

Castro, R. M. Serviço Turístico Informal: Uma Reflexão Sobre o Aspecto Ambiental, Social e Econômico Dessa Prática Na Cidade De Manaus-Am. Dissertação defendida no Programa De Pós-Graduação em Ciểncias do Ambiente e Sustentabilidade na Amazônia- PPGCASA. Universidade Federal Do Amazonas - UFAM, 2015.

Coraggio, J. L. Da Economia dos Setores Populares à Economia do Trabalho". Rio de Janeiro, Vozes, 2000.

Gil, A. C. Métodos e Técnicas da Pesquisa Social. 6ª Edição. São Paulo: Atlas 2008.

Hall, C. M. \& Boyd, S. Nature-based Tourism in Peripheral Areas: Development or Disaster?, 2005.

Hall, C. M.; Müller, D. K.; Saarinen, J. Changement climatique, authenticité et marketing des régions nordiques: Conséquences sur le tourisme finlandais et la «plus grande marque au monde» ou "Les changements climatiques finiront-ils par tuer le père Noël?». Téoros, v. 28 , n. 1 , p. $70-79,2009$.

Irving, M. A. Reinventando a reflexão sobre turismo de base comunitária. In: bartholo, R., sansolo, D. G. e Bursztyn, I. (Orgs). Turismo de Base Comunitária: diversidade de olhares e experiências brasileiras. Rio de Janeiro: Letra e Imagem, 2009.

Krein, J. D. \& Proni, M. W. Economia informal: aspectos conceituais e teóricos. Brasilia: OIT, 2010 Vol.1 (Série Trabalho Decente no Brasil ; Documento de trabalho n.4).

Maldonado, C. Turismo Rural Comunitário na América Latina. IN: Bartholo R.i Ansolo D. G.i Bursztyn, I. (Organizadores). Turismo de base comunitária: diversidade de olhares e experiências brasileiras / - Rio de Janeiro: Letra e Imagem, 2009.

Mandrysz, W. Community-Based Social Economy - Social Capital and Civic Participation in Social Entrepreneurship and Community Development. Management Dynamics in the Knowledge Economy, Vol.8 (2020) 
no.1, 81-93. DOI 10.2478, 2020

Marzuki, A.; Rofe, M.; Hashim, N. A. M. Disputes on naturebased tourism development in northern peninsular Malaysia. Tourism Analysis, v. 19, n. 4, p. 525-530, 2014.

Mehmetoglu, M. Typologising nature-based tourists by activity - Theoretical and practical implications. Tourism Management, v. 28, n. 3, p. 651-660, 2007.

Sachs, I. Inclusão Social Pelo Trabalho Decente: oportunidades, obstáculos, políticas públicas. Estudos Avançados 18 (51), 2004 - ISSN 010340140, versão on-line ISSN 1806-9592.

Sachs, I. Inclusão Social Pelo Trabalho: Desenvolvimento Humano, Trabalho Decente e o Futuro dos Empreendedores de Pequeno Porte do Brasil. Rio de Janeiro: Garamond, 2003.

Sampieri, R. H.; Collado, C. F.; Lucio, M. P. B. Metodologia de Pesquisa. $5^{\text {a }}$ Edicão - Porto Alegre: Penso, 2013. ISBN: 978-85-65848-28-2

Silva, G. T.; Chaves, P. C. P. R.; Simonetti, S. R. Turismo comunitário: diagnóstico das atividades turísticas na comunidade Bela Vista do Jaraqui (Manaus-AM). Paper do NAEA 2020, Volume 29, No 3. ISSN: 15169111.

SINGER, Paul. Introdução a Economia Solidária. São Paulo: Editora, Fundaçã̃o Perseu Abramo, 2002.

Tiriba, L. Ciência econômica e saber popular: reivindicar o popular na economia e na educação. In L. Tiriba, \& Picanço, L. (Orgs.), Trabalho e educação: arquitetos, abelhas e outros tecelões da economia popular solidária São Paulo: 2003.

Tiriba, L. Economia Popular e Cultura do Trabalho. Editora: Uniju, São Geraldo, ljuí - RS, 2001.

Tiriba, L. O trabalho no olho da rua: Fronteiras da economia popular e da economia informal, 2004.

Tiriba, L. Educação Popular e Pedagogia(s) da Produção Associada. Campinas, vol. 27, 2007

Viceconti, P. E. V. \& Neves, S. Introdução a Economia. $2^{\text {a Edi- }}$ ção. São Paulo: Frase Editora, 1996.

Winter, P. L. et al. Outdoor recreation, nature-based tourism, and sustainability. Sustainability (Switzerland), v. 12, n. 1, p. $1-12,2020$.

World Tourism Organization. UNWTO Annual Report 2017. Publicado em maio de 2028. ISBN: 978-92-844-19807 / ISBN: 978-92-844-1979-1.

Zaoual, H. Nova economia das iniciativas locais: uma introducão ao pensamento pós-global. Traducão de Michel Thiollent. Rio de Janeiro DP\&A: Consulado Geral da França: COPE/UFRJ, 2006. 